\title{
Mikročipiranje životinja i mogući neželjeni učincỉ u veterinarskoj medicini
}

\author{
Tihana Josipović, Hrvoje Capak*, Lucija Ciglar i Krešimir Martinković
}

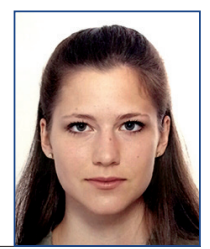

\section{Sažetak}

Mikročipiranje se pokazalo najkorisnijom metodom označavanja životinja u veterinarskoj medicini i stočarstvu. Zbog visoke učinkovitosti i jednostavne primjene vrlo brzo je doseglo globalne razmjere. U Republici Hrvatskoj mikročipiranje smiju obavljati samo ovlašteni veterinari koji su dužni slijediti zakonski propisane upute o načinu implantacije. Mikročip je pasivan uređaj i svojom prisutnošću ne šteti organizmu. Od početka njegove uporabe kao uređaja za označavanje životinja, prijavljeno je svega nekoliko slučajeva nuspojava i istraživanja $u$ svrhu proučavanja njegove

biokompatibilnosti s organizmom. Među najčešćim neželjenim učincima spominju se pretjerane reakcije organizma, tumori, pogrešna implantacija te migracija kao daleko najzastupljenija pojava. Iako su nuspojave moguće, današnjim napretkom tehnologije, usavršavanjima u području biokompatibilnosti te trajanju mikročipova, njihov rizik sveden je na minimum. Uz sve navedeno, odgovornost veterinara za pravilnu implantaciju ima znatnu ulogu u smanjivanju tog rizika.

Ključne riječi: životinje, označavanje, identifikacija, mikročip, mikročipiranje

\section{Uvod}

Uporaba mikročipa, kao uređaja za označavanje životinja, započela je sredinom 80-ih godina prošlog stoljeća. Zbog svoje jednostavne primjene i pozitivnog odjeka u veterinarskoj medicini i stočarstvu, mikročipiranje se vrlo brzo populariziralo i doseglo svjetske razmjere. Ostale metode identifikacije životinja poput tetoviranja, žigosanja, zarezivanja uški i slično počele su gubiti na značenju i sve se manje primjenjuju. Mikročipiranje se pokazalo

jednom od najsigurnijih metoda koja, $\mathrm{u}$ usporedbi s ostalima, najviše brine o dobrobiti životinja. Osim navedenih pozitivnih osobina, karakterizira ju i visoki stupanj učinkovitosti koji se može potvrditi brzom identifikacijom izgubljenih životinja (najčešće pasa) i brzom pronalasku njihovih vlasnika. Iako se trenutno smatra najboljim izborom za označavanje životinja, ne smije postati zamjena za njihovu vanjsku identifikaciju (Lord i sur., 2008.). U većini razvijenih

Tihana JOSIPOVIĆ, dr. med. vet., Brežice, Slovenija; dr. sc. Hrvoje CAPAK ${ }^{*}$, dr. med. vet., docent, (dopisni autor, e-mail: hcapak@vef.hr), Lucija CIGLAR, studentica, Krešimir MARTINKOVIĆ, dr. med. vet., univ. mag. med. vet., Veterinarski fakultet Sveučilišta u Zagrebu, Zagreb, Hrvatska 
zemalja obvezno je mikročipiranje pasa, a $\mathrm{u}$ nekim zemljama i konja. Vlasnici kućnih ljubimaca sve češće traže uslugu mikročipiranja mačaka, pitomih vretica, ali i ostalih, manje zastupljenih vrsta. Za potrebe istraživanja, u svrhu lakše identifikacije prilikom izvođenja pokusa, mikročipiranje se provodi i na laboratorijskim životinjama.

\section{Mikročipiranje u Republici Hrvatskoj}

Članak 2. Pravilnika o označavanju pasa (NN 72/2010.) strogo definira značenje pojma mikročipa, kao „Samoočitavajuće pasivne naprave s radiofrekvencijom koja udovoljava ISO 11784 standardu (...) i može se očitati s napravom koja je kompatibilna s ISO 11785 standardom, na minimalnoj udaljenosti od $12 \mathrm{~cm} .{ }^{\prime \prime}$ Mikročip je veličine zrna riže, trajan je te prati psa od označavanja do uginuća (NN 72/2010.). U Republici Hrvatskoj obvezno mikročipiranje pasa provodi se od 2004. godine (NN 162/2003.). Pravilnikom o označavanju pasa strogo je određen način na koji se označavanje mikročipom treba provoditi: dopuštenje za njegovo provođenje ima samo licencirani veterinar, mikročip se aplicira u aseptičkim uvjetima, a mjesto aplikacija

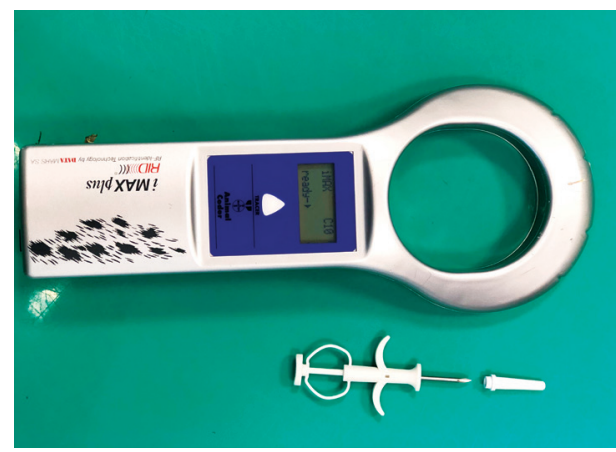

Stika 1. Čitač mikročipova i iskorišteni jednokratni aplikator u čijoj se igli prije aplikacije nalazi mikročip s jedinstvenim petnaesteroznamenkastim kodom. je perenteralno, u potkožje. Aplikacija se vrši pomoću jednokratnog aplikatora koji dolazi u pakiranju s mikročipom i pripadajućim jedinstvenim kodom. Za Hrvatsku i dio Europe propisana je aplikacija u središnjem dijelu regije vrata lijeve strane životinje. Uobičajeno mjesto mikročipiranja u Americi i Ujedinjenom Kraljevstvu jest međulopatično područje, što nas prilikom identifikacije pasa uvezenih iz tih dijelova svijeta može zbuniti.

Prilikom mikročipiranja podatci se unose $u$ Središnji upisnik pasa tzv. Lysacan sustav, dostupan na internetskoj stranici koju službeno vodi Ministarstvo poljoprivrede (Uprava za veterinarstvo i sigurnost hrane). Lysacan sustav sadržava podatke o vlasniku, nacional životinje, identifikacijski broj mikročipa, datum aplikacije i druge informacije. Uz mikročipiranje, propisano je obvezno cijepljenje pasa protiv bjesnoće te se i podatci o cijepljenju upisuju u sustav. Umrežavanjem podataka na nacionalnoj razini postignuta je jednostavna identifikacija bilo kojeg mikročipiranog psa uz pomoć čitača i pristupa Lysacan sustavu. Mikročip u sebi sadrži kôd od 15 brojčanih znamenki koji se sastoji od kôda države podrijetla životinje, kôd proizvođača te jedinstvenog broja psa. Od 13. lipnja 2011. godine propisana je

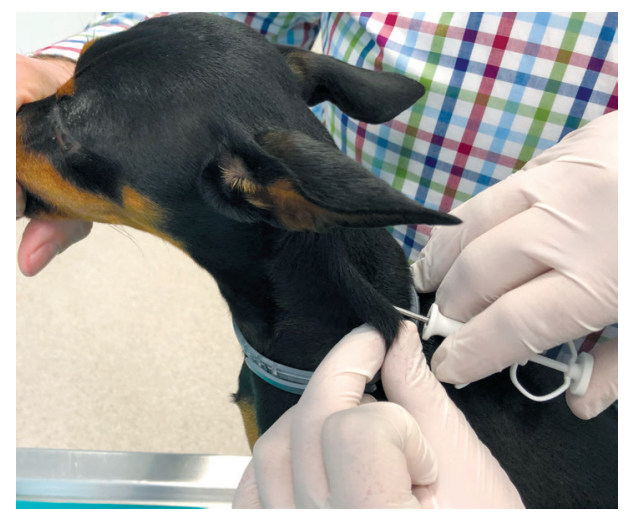

Slika 2. Prikaz aplikacije mikročipa u potkožje lijeve strane vrata psa. 
obveza da svaki pas u Republici Hrvatskoj treba biti mikročipiran i uveden u Lysacan sustav 90 dana od štenjenja. Od svibnja 2018. godine, primjenom Opće uredbe o zaštiti podataka (GDPR) Europskog parlamenta i Vijeća Europske unije (2016/679), strogo je zabranjeno odavanje podataka iz Lysacan sustava osobama koje nemaju pristup tom sustavu. Ako je osoba pronašla životinju i dovela je na identifikaciju u veterinarsku ambulantu, ovlašteni veterinar je dužan kontaktirati vlasnika o pronalasku životinje.

\section{Struktura i način rada mikročipa}

Tip mikročipa nije propisan, no $u$ državama članicama EU uobičajena je uporaba mikročipova koji odgovaraju ISO standardu 11784 ili 11785 još od 90ih godina prošlog stoljeća (Hogewerf i Klooster, 2003.). Svaki se mikročip sastoji od 4 esencijalna dijela: silikonskog čipa, kondenzatora, metalne zavojnice antene i kapsule (Saito i sur., 2010.). Uređaj je po svojoj prirodi pasivan, tj. nema vlastiti izvor napajanja. Mikročip koristi tehnologiju identifikacije radiofrekvencijom, (engl. 'radio-frequency identification - RFID'). Citači mikročipova šalju radiovalove niske frekvencije koji aktiviraju mikročip elektromagnetskom indukcijom. On se pritom aktivira i šalje povratne valove koje pritom čitač detektira na zaslonu prikazom koda mikročipa (Razvi i sur., 2016.). Kapsula je cilindričnog oblika, građena od biokompatibilnog stakla kako bi organizam prihvatio strano tijelo bez pretjerane reakcije. Mikročip i aplikator moraju biti potpuno sterilni kako bi izbjegli moguće nuspojave.

\section{Reakcija organizma}

Ubrzo nakon aplikacije dolazi do uobičajene prolazne lokalne upalne reakcije organizma na strano tijelo koju prati stvaranje fibrozne kapsule (Linder i sur., 2009., Gerber i sur., 2012.). Lokalna upalna reakcija nastaje prije svega zbog oštećenja endotela i degradacije fosfolipazne membrane (Taira i sur., 1992.). Ona nam je potrebna da bi se mikročip zadržao u poziciji i ne smijemo ju zamijeniti s infekcijom. Mjesec dana nakon aplikacije mikročip se nalazi inkapsuliran na mjestu gdje je apliciran. Okružuje ga samo granulacijsko tkivo s minimalnim naznakama edema i hemoragije (Saito i sur., 2010.).

Brojna istraživanja posvećena su ispitivanju presvlaka na kapsuli od različitih materijala, kako bi im se ustvrdila biokompatibilnost i dokazala njihova pozitivna svojstva. Većina mikročipova danas je presvučena polipropilenskom presvlakom na prednjem dijelu kapsule koja osigurava biokompatibilnost $\mathrm{s}$ organizmom i djeluje tako da promiče stvaranje kapsule oko mikročipa poticanjem rasta vezivnog tkiva i drugih stanica (Razvi i sur., 2016.). Istraživanje na miševima (Ghantan i Edmondson, 1990.) pratilo je reakciju tkiva i poziciju 140 implantiranih mikročipova presvučenih polipropilenskom presvlakom kroz period od 2 godine. U većine čipiranih miševa došlo je do stvaranja kapsule oko mikročipa koja je sadržavala fibrocite i zrela kolagena vlakna. Tkivna kapsula oko mikročipa je bila više celularna 3 i 15 mjeseci od implantacije, od one nakon 24 mjeseca. Minimalni do umjereni upalni odgovor s limfocitima, makrofazima, neutrofilima i nekoliko plazma stanica mogao se uočiti u prvopregledanih miševa. Kod samo 2 implantata u cjelokupnom istraživanju uočena je kronična granulomatozna upala.

Lambooij i sur. (1992.) proveli su istraživanje na prasadi proučavajući odgovor potkožnog tkiva na presvlaku od polietilen tereftalata (PET). Došli su do zaključka da odgovor organizma može rezultirati trima različitim obrascima reakcija: jednostavnom 
inkapsulacijom (nakon eksudativne faze, mikročip je ostao izravno okružen vlaknastom kapsulom, a njena debljina nije se mijenjala od 21. dana nakon implantacije), inkapsulacijom s upalnom reakcijom (nakon opisane početne faze zadržala se upalna reakcija koja je prešla u subakutni oblik, a kao rezultat toga povećala se debljina kapsule), koja je nastala, najvjerojatnije, zbog prisutnosti dlaka i epidermalnih ostataka ili reakcije na PET, ili formacijom apscesa (nastao, najvjerojatnije, nedostatkom sterilnosti postupka, uz reakciju na PET presvlaku).

Beucken i sur. (2007.) ispitivali su biološki odgovor organizma na DNKpresvlaku u usporedbi s mikročipovima koji su imali samo staklenu kapsulu bez presvlake, in vitro koristeći stanične kulture $\mathrm{i}$ in vivo na laboratorijskim štakorima. Nakon 4 tjedna tkivo je na jednak način reagiralo na sve vrste implantata. Došlo je do formiranja vlaknaste kapsule u kojoj su fibrociti bili jasno razlučeni od okolnog izvornog vezivnog tkiva. Kapsula se sastojala od kolagena i nekoliko slojeva fibrocita. $\mathrm{Ni}$ kapsula niti njena okolina nije sadržavala upalni infiltrat. Sličan rezultat dobili su i 12 tjedana od implantacije, odgovor organizma bio je jednak na sve vrste implantata. Mikročipovi su bili okruženi zrelom fibroznom kapsulom bez prisustva upalnog infiltrata ili multinuklearnih fagocitnih stanica. Debljina svih kapsula je bila između 5 i 30 slojeva fibroblasta $\mathrm{u}$ oba istraživana perioda od implantacije, neovisno o vrsti implantata.

Do danas, reakcije organizma na mikročip istražene su na većini domaćih životinja i kućnih ljubimaca. U većini zemalja EU označavanje konja mikročipom postalo je obvezno (Wulf i sur., 2013.a), stoga su provedena brojna istraživanja utjecaja mikročipiranja na konje. Iako je ono postalo obvezno, u konja se još uvijek zadržalo i označavanje paljenim žigom kao alternativ- na metoda identifikacije za pojedina grla (Barać i sur., 2014.). U istraživanju utjecaja opaljivanja žigom u usporedbi s mikročipiranjem na stupanj boli i upalnu reakciju koju stvaraju prilikom označavanja, Lindegaard i sur. (2009.) zaključili su da mikročipiranje stvara znatno manji stupanj boli i upale te ne stvara dugoročni zdravstveni rizik koji može nastati opaljivanjem žigom i donose preporuku za napuštanje žigosanja kao metode označavanja konja. U istraživanju Wulf i sur. (2013.a) potvrđene su dosadašnje spoznaje o reakciji organizma na mikročipiranje. Iznimka su 2 konja u kojih se pojavila granulomatozna reakcija. U jednog, okolno se tkivo sastojalo od nezrelog granulacijskog tkiva i granulomatoznog miozitisa bez prisustva inkapsulacije. U drugom slučaju uočeni su makrofagi i multinuklearne divovske stanice, kao i limfociti i eozinofili u okolini mikročipa koji je bio uredno inkapsuliran. U oba slučaja mikročipovi su imali PET presvlaku. Uz navedeno, istražili su i postotak uspješnosti očitavanja mikročipova trima različitim čitačima, na uzorku od 428 konja. Uspješnost je bila do $100 \%$ na strani vrata u kojoj se mikročip nalazio. Dokazali su da je uspjeh očitanja najviše ovisio o dobi, ali ne i o pasmini. Potvrdili su da je mikročipiranje vrlo pouzdana i biokompatibilna metoda označavanja konja. $U$ istoj godini objavljeno je istraživanje koje je proučavalo odgovor konja i uspješnost očitavanja mikročipova reducirane veličine (manji od konvencionalnih). Kao tjelesni odgovor konja na stres mjerili su koncentraciju kortizola u slini, frekvenciju i ritmičnost rada srca. Zaključili su da su smanjeni mikročipovi vrlo pouzdani za identifikaciju, a njihova implantacija pritom ne prouzroči stres. U usporedbi s konvencionalnim mikročipovima, veličina nije utjecala na uspješnost očitavanja (Wulf i sur., 2013.b). 


\section{Opasnosti i neželjeni učinci mikročipiranja}

\section{Tumori su rijetka pojava}

Iako vrlo rijetko, jedna od mogućih nuspojava povezanih $\mathrm{s}$ implantacijom mikročipova jest stvaranje tumora na mjestu aplikacije. Do sada je objavljeno nekoliko istraživanja na miševima i prikaza slučajeva u kućnih ljubimaca koji upućuju na povezanost tumora s mikročipiranjem. Među njima se ističe prikaz slučaja liposarkoma, u psa križanca starosti 11 godina, koji se razvio unutar 11 mjeseci od mikročipiranja (Vascellari, 2004.), kao prvi objavljeni slučaj razvoja tumora povezanog s mikročipiranjem u kućnih ljubimaca. Autori opisuju kako se masa formirala oko samog mikročipa te je kirurškom obradom tumor, zajedno s marginama i mikročipom u središtu, odstranjen uz uspješno postoperativno cijeljenje rane. U još jednom slučaju autori su potvrdili nastanak infiltrativnog fibrosarkoma u francuskog buldoga starog 9 godina (Vascellari i sur., 2006.). Pas je mikročipiran 7 mjeseci prije utvrđivanja tumorske mase. Patohistološkom pretragom tumor je imao karakteristike mačjeg postvakcinalnog sarkoma no, zbog cijepljenja psa u istom području, nisu mogli sa sigurnošću etiološki dokazati podrijetlo tumora.

Slučaj povezan s mikročipiranjem kućne rovke (Suncus murinus), navodi kako je unutar jednog tjedna od mikročipiranja došlo do naglog rasta potkožne mase u međulopatičnom području. Zbog brzog širenja i agresivnosti tumora, životinja je eutanazirana, a masa je patohistološki pregledana. Tumorska masa je bila slabo demarkirana, neinkapsulirana, infiltrativna i pritiskala je potkožno tkivo i kožu. U središtu mase nalazio se mikročip. Fenotipski neoplastične stanice podsjećale su na sarkom induciran stranim tijelom. U odnosu na druge vrste životinja, u mačaka je poznato da cijepljenje može prouzročiti pojavu postvakcinalnog sarkoma $\mathrm{s}$ većom pojavnosti (Schutt i Turner, 2010.). U prikazu slučaja Carminato i sur. (2011.), prvi put je ustvrđeno da je sarkom u mačke etiološki nastao zbog aplikacije mikročipa, a ne kao posljedica cijepljenja. U devetogodišnje mačke uočili su potkožnu masu u području vrata. Nakon kirurške obrade mikročip je pronađen $u$ središtu mase, a patohistološke karakteristike bile su slične onima kod nalaza mačjeg postvakcinalnog sarkoma. Mačje postvakcinalne fibrosarkome karakterizira upalna peritumoralna infiltracija, multinuklearne divovske stanice i miofibroblastične stanice (Dubielzig, 1993.).

Istraživanja povezanosti mikročipiranja s nastankom tumora provođena su većinom na laboratorijskim miševima i štakorima (Tillmann i sur., 1997., Blanchard i sur., 1999., Elcock i sur., 2001.). Svi tumori opisani u ovim radovima bili su mezenhimalnog podrijetla i sadržavali su ugrađene mikročipove. Mehanizam kancerogenosti pripisan je reakciji organizma na strano tijelo (Elcock i sur., 2001.).

Podatci prikupljeni tijekom godina upućuju da lokalna upala, prouzročena aluminijem ili drugim potencijalno nadražujućim inokuliranim tvarima, može potaknuti tkivo na tumorski razvoj. Prije više od 100 godina, znanstvenici su primijetili da su iritacija, upala $\mathrm{i} / \mathrm{ili}$ rane promotori razvoja tumora (Macy i Hendrick, 1996.). Gotovo sve što prouzroči lokalnu upalnu reakciju može potencijalno biti odgovorno za neoplastičnu inicijaciju (Withrow i MacEwen, 2001.). Sve navedeno potvrđuje koliko je bitan sterilan i aseptički pristup označavanju mikročipom, kao i ulaganje u razvoj što kvalitetnije strukture, a time i biokompatibilnosti mikročipa s organizmom. 


\section{MRI, da ili ne?}

Kao što je ranije navedeno, mikročip u svojoj strukturi sadrži i metalne komponente. Izvedba magnetske rezonancije (MR) u prisutnosti metalnog uređaja podiže zabrinutost zbog potencijalnih komplikacija poput migracije implantata, ozljede toplinom ili izobličenja MR snimke (Suh i sur., 1998., Kangarlu i Robitaille, 2000., Shellock i Crues, 2004.). Metalni sastav varira ovisno od proizvođača mikročipova. Vrsta metala i njegova struktura imaju znatan utjecaj na pojavu artefakta. Eksperimentalno nije pronađeno oštećenje tkiva prouzročeno toplinom u životinja podvrgnutih MR-u, kao ni migracija mikročipa. No, prilikom istraživanja utjecaja topline treba uzeti u obzir električna svojstva metala (magnetsku osjetljivost, električnu otpornost i toplinsku vodljivost) (Saito i sur., 2010.). Uz navedeno, veličina i oblik mikročipa, orijentacija u usporedbi s magnetskim poljem, jačina magnetskog polja, trajanje RF pulsa i drugo mogu biti čimbenici koji utječu na stvaranje topline (Ho, 2001., Muranaka i sur., 2005.). Jedini problem koji se pojavio su bili artefakti na dijagnostičkoj MR snimci nastali zbog mikročipa. Područje gdje je mikročip pozicioniran postaje teže za interpretaciju određenih promjena, stoga bolesti kralježnice (posebice vratnog i grudnog dijela) mogu biti teže dijagnosticirane. Također, snimka mozga može biti zahvaćena artefaktom u malih životinja. Iz tog razloga je poželjno implantirati mikročipove u drugom području u pasmina za koje je poznato da su predisponirane za poremećaje vratnog dijela kralježnične moždine i malih pasmina s relativno čestom predispozicijom na bolesti mozga. Psi označeni mikročipovima bili su skenirani bez ikakvih nuspojava, a mikročipovi su poslije bili uspješno očitani.

\section{Implantacija kao stručna greška}

Označavanje životinja mikročipiranjem u Hrvatskoj smije obavljati jedino ovlašteni veterinar (NN, 72/2010.). Ako se osoba prilikom označavanja drži propisanih uputa (npr. mjesta i načina implantacije) ne može doći do pogreške zbog izvođenja postupka. Od kada se mikročipiranje počelo redovito provoditi, objavljeno je svega nekoliko slučajeva pogrešnih implantacija koje su prouzročile bolest i imale štetan utjecaj na životinju. U svim objavljenim slučajevima pogrešna implantacija $u$ pasa rezultirala je ozljedom kralježnične moždine zbog pozicioniranja mikročipa u međukralježničnom kanalu (Platt i sur., 2007., Smith i Fitzpatrick, 2009.). Došlo je do akutne pojave neuroloških znakova, ali nakon kirurške intervencije životinje su se uspješno oporavile. Jedini prolongirani slučaj ozljede kralježnične moždine opisan je $u$ trogodišnjeg jorkširskog terijera kojemu su se znaci progresivne hromosti lijeve prednje noge i tetrapareza pojavili 3 godine od mikročipiranja (Joslyn i sur., 2010.). U ovom slučaju pretpostavili su da je mikročip bio apliciran $u$ interarkuatni C5-C6 ligament i dorzalno vratno mišićje. Operacijom je mikročip ekstrahiran i životinja je vratila lokomotorne funkcije za 2 tjedna, sa zaostalim slabim proprioceptivnim deficitom prednje lijeve i stražnjih nogu. Hromost je u potpunosti nestala. Jedini slučaj pogrešne implantacije mikročipa koji je prouzročo emboliju opisan je u čileanskog plamenca (Olds i sur., 2016.). Nakon ustvrđivanja embolusa u ilijačnoj arteriji pomoću rendgenografije i kompjuterske tomografije pristupili su njegovom kirurškom uklanjanju, no životinja je tijekom operacije uginula. Obdukcijom je ustvrđeno oštećenje descendentne aorte koja je najvjerojatnije bila mjesto ulaska mikročipa u krvožilni sustav.

\section{Migracija mikročipa - najzastupljeniji neželjeni učinak}

Prethodno navedene slučajeve, iako su evidentno rezultat pogreške pri implantaciji mikročipa, možemo po- 
vezati i s njegovom migracijom. Prestanak rada mikročipa je moguća, ali vrlo rijetko zabilježena pojava. Njegova migracija je također rijetka, ali definitivno najzastupljenija komplikacija (BSAVA, 2002.), s regijom lakta i ramena kao najčešćim mjestima njegova pronalaska kod malih životinja (Swift, 2000., BSAVA, 2002.). Mikročipovi implantirani u rameno područje imaju veću vjerojatnost migracije od onih implantiranih u druga, preporučena područja (Jansen i sur., 1999.).

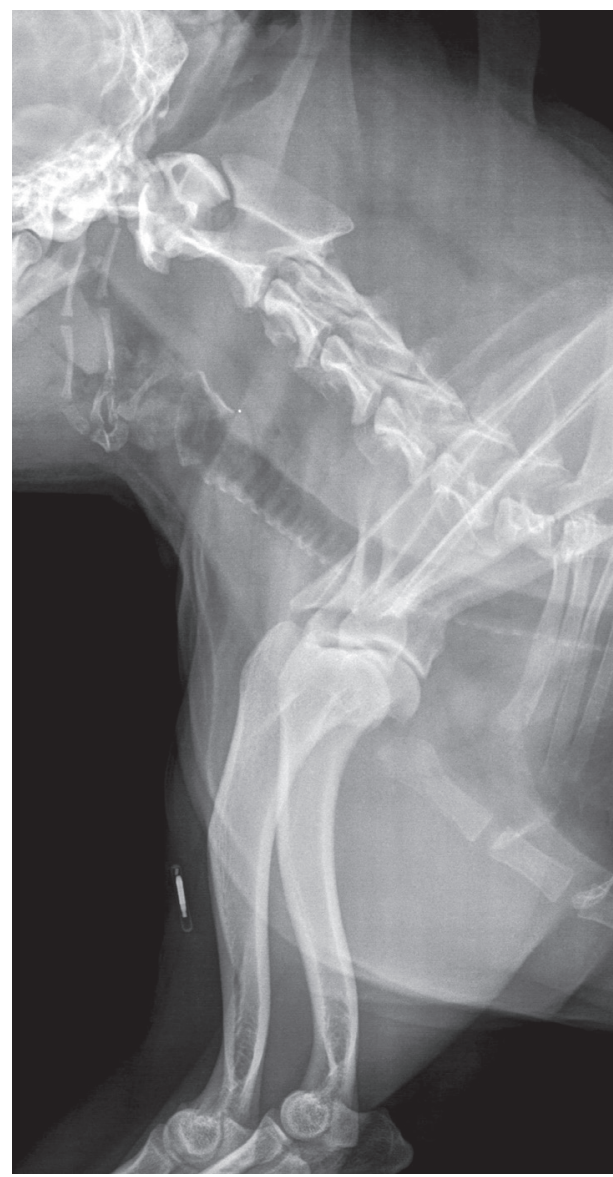

Slika 3. Slučajan rengenski nalaz migracije mikročipa u psa (bostonski terijer, star 6 godina) u područje srednje trećine nadlatice. $\mathrm{Na}$ istom rengenskom prikazu nalazi se područje vrata gdje nalaz mikročipa izostaje.
Razlozi migracije mikročipova nisu u potpunosti poznati niti razjašnjeni. Jedini logičan zaključak koji se nameće jest kako nije došlo do predviđene lokalne reakcije organizma prilikom i neposredno po aplikaciji mikročipa, koja bi isti zadržala u poziciji, kao što je prethodno opisano. Migracija, općenito gledajući, ne predstavlja problem za životinju osim ako mikročip ne migrira u specifično područje tijela (u zglobni prostor, krvnu žilu i sl.), prouzročivši komplikacije tog dijela organskog sustava životinje. Potencijalni problem može predstavljati pri brzoj identifikaciji životinja, pri kojoj se trenutno ne očita signal na predviđenom mjestu, $u$ takvim prilikama preporuka je prijeći čitačem što veću površinu, a ponekad i cijelo tijelo životinje.

\section{Zaključak}

Popularizacijom mikročipiranja ostale metode označavanja životinja, poput žigosanja ili tetoviranja, polako gube na značenju te se sve manje primjenjuju. Mikročipiranje je doseglo globalnu raširenost, jer se pokazalo najučinkovitijom metodom identifikacije, utvrđivanja vlasništva, posebice $u$ izgubljenih ili ukradenih životinja. Njegovim uvođenjem olakšano je i praćenje podataka o broju životinja, kao i procijepljenosti populacije. Umrežavanje tih podataka donijelo je pozitivan odjek u Hrvatskoj kao i u drugim zemljama. Kako bi se tehnologija proizvodnje mikročipova tijekom vremena usavršavala, veterinari bi trebali prijaviti svaki slučaj u kojem je, unatoč pravilnoj implantaciji, došlo do bilo kojeg oblika nuspojava. Migracija se ističe kao najčešći oblik koji u većini slučajeva ne nanosi štetu životinji. Prema do sada dostupnim podatcima možemo je protumačiti jedino kao izostanak reakcije organizma na strano tijelo, no broj istraživanja koji bi mogao potvrditi ili objasniti njezin nastanak je nedovoljan. Ostale zabilje- 
žene nuspojave su vrlo rijetke i nemaju značenje $u$ usporedbi sa svim prednostima koje mikročipiranje životinja donosi. Dosadašnjim istraživanjima ustvrđena je njegova minimalna invazivnost, jednostavna i sigurna primjena u veterinarskoj medicini.

\section{Literatura}

1. Anon. (2010): Pravilnik o označavanju pasa. Narodne novine, br. 162/2003.

2. Anon. (2010): Pravilnik o označavanju pasa. Narodne novine, br. 72/2010.

3. Anon. (2016): Uredba (EU) Europskog Parlamenta i Vijeća, 2016/679.

4. BARAĆ, Z., Ž. FATOVIĆ, D. SOLIĆ, F. POLJAK, D. TADIĆ, M. ČABRAJEC, M. ŠABANOVIĆ, M. ŽALAC, P. BAGOVIĆ i M. ČAČIĆ (2014): Postupci i upute za označavanje i upis podataka u Središnji registar kopitara. Hrvatska poljoprivredna agencija, Križevci.

5. BEUCKEN VAN DEN, J. J. J. P., I. X. F. WALBOOMERS, I. M. R. J. VOS, N. A. J. M. SOMMERDIJK, R. J. M. NOLTE and J. A. JANSEN (2007): Biological Responses to Multilayered DNACoatings. J. Biomed. Mater. Res. B 81, 231-238.

6. BLANCHARD, K. T., C. BARTHEL, J. E. FRENCH, H. E. HOLDEN, R. MORETZ, F. D. PACK, R. W. TENNANT and R. E. STOLL (1999): Transponderinduced sarcoma in the heterozygous p53+/2 mouse. Toxicol. Pathol. 27, 519-527.

7. BSAVA REPORT (2002): Keeping track of microchip adverse reactions. J. Small Anim. Pract. 43, 570.

8. CARMINATO, A., M. VASCELLARI, W. MARCHIORO, E. MELCHIOTTI and F. MUTINELLI (2011): Microchip-associated fibrosarcoma in a cat. Vet. Dermatol. 22, 565-569.

9. DUBIELZIG, R. R., K. L. HAWKINS and P. E. MILLER (1993): Myofibroblastic sarcoma originating at the site of rabies vaccination in a cat. J. Vet. Diagn. Invest. 5, 637-638.

10. ELCOCK, L. E., B. P. STUART, B. S. WAHLE, H. E. HOSS, K. CRABB, D. M. MILLARD, R. E. MUELLER, T. F. HASTING and S. G. LAKE (2001): Tumors in long-term rat studies associated with microchip animal identification devices. Exp. Toxicol. Pathol. 52, 483-491.

11. GERBER, M. I., A. M. SWINKER, W. B. STANIAR, J. R. WERNER, E. A. JADRZEJEWSKI and A. L. MARCINA (2012): Health factors associated with microchip insertion in horses. J. Equine Vet. Sci. 32, 177-182.

12. GHANTAN, R. and J. EDMONDSON (1990): Tissue Reaction to an Implantable Identification Device in Mice. Toxicol. Pathol. 18, 412-416.

13. HO, H. S. (2001): Safety of metallic implants in magnetic resonance imaging. J. Magn. Reson. Imaging 14, 472-477.
14. HOGEWERF, P. and K. VAN 'T KLOOSTER (2003): ISO WG3 summary on the evolution of microchip technology for companion animals. WSAVA. https://www.wsava.org/WSAVA/media/PDF_old/ ISO-a-Brief-Historical-Overview.pdf

15. JANSEN, J. A., J. P. C. M. VAN DER WAERDEN, R. H. GWALTER and S. A. B. VAN ROOY (1999): Biological and migrational characteristics of transponders implanted into beagle dogs. Vet. Rec. 145, 329-333.

16. JOSLYN, S. K., P. G. WITTE and H. W. SCOTT (2010): Delayed spinal cord injury following microchip placement in a dog. Vet. Comp. Orthop. Traumatol. 3, 214-217.

17. KANGARLU, A. and P. M. L. ROBITAILLE (2000): Biological effects and health implications in magnetic resonance imaging. Concept. Magnetic Res. 12, 321-359.

18. LAMBOOIJ, E., P. H. S. DE GROOT, R. F. MOLENBEEK and E. GRUYS (1992): Subcutaneous tissue reaction to polyethylene terephtalate-covered electronic identification transponders in pigs. Vet. Quart. 14, 145-147.

19. LINDEGAARD, C., D. VAABENGAARD, M. T. CHRISTOPHERSEN, C. T. EKSTØM and J. FJELDBORG (2009): Evaluation of pain and inflammation associated with hot iron branding and microchip transponder injection in horses. Am. J. Vet. Res. 70, 840-847.

20. LINDER, M., S. HUTHER and M. REINACHER (2009): In vivo reactions in mice and in vitro reactions in feline cells to implantable microchip transponders with different surface materials. Vet. Rec. 165, 45-50.

21. LORD, L. K., M. L. PENNELL, W. INGWERSEN and R. A. FISHER (2008): Sensitivity of commercial scanners to microchips of various frequencies implanted in dogs and cats. J. Am. Vet. Med. Assoc. 233, 1729-1735.

22. MACY, D. W. and M. J. HENDRICK (1996): The potential role of inflammation in the development of postvaccinal sarcomas in cats. Vet. Clin. North Am. Small Anim. Pract. 26, 103-109.

23. MURANAKA, H., O. NAKAMURA, S. USUI, Y. UEDA and K. MORIKAWA (2005): Influence of implants on human body during MRI examinations: fundamental experiment using metal balls. Nippon Hoshasen Gijutsu Gakkai Zasshi. 61, 1014-1020.

24. OLDS, J. E., J. EWING, P. ARRUDA, J. KUYPER, E. RIEDESEL and K. M. MILES (2016): Iatrogenic microchip arterial embolism in a Chilean flamingo (Phoenicopterus chilensis). J. Zoo Wildlife Med. 47, 686-690.

25. PLATT, S., L. WIECZOREK, R. DENNIS and A. DE STEFANI (2007): Spinal cord injury resulting from incorrect microchip placement in a cat. J. Feline Med. Surg. 9, 157-160.

26. RAZVI, R., P. A. PARA and S. GANGULY (2016): Implantation of Microchip in Animals: A Review. Int. J. Phar. \& Biomedi. Res. 3, 19-20. 
27. SAITO, M., S. ONO, H. KAYANUMA, M. HONNAMI, M. MUTO and Y. UNE (2010): Evaluation of the Susceptibility Artifacts and Tissue Injury Caused by Implanted Microchips in Dogs on 1.5 T Magnetic Resonance Imaging. J. Vet. Med. Sci. 72, 575-581.

28. SCHUTT, L. K. and P. V. TURNER (2010): Microchip-Associated Sarcoma in a Shrew (Suncus murinus). J. Am. Assoc. Lab. Anim. 49, 638-641.

29. SHELLOCK, F. G. and J. V. CRUES (2004): MR procedures: biologic effects, safety, and patient care. Radiology 232, 635-652.

30. SMITH, T. J. and N. FITZPATRICK (2009): Surgical removal of a microchip from a puppy's spinal canal. Vet. Comp. Orthop. Traumatol. 22, 63-65.

31. SUH, J. S., E. K. JEONG, K. H. SHIN, J. H. CHO, J. B. NA, D. H. KIM and C. D. HAN (1998): Minimizing artifacts caused by metallic implants at MR imaging: experimental and clinical studies. Am. J. Roentgenol. 171, 1207-1213.

32. SWIFT, S. (2000): Microchip adverse reactions. J. Small Anim. Pract. 41, 232.

33. TAIRA, T., T. FUJINAJA, K. TAMURA, M. IZUMO, H. ITOH, N. TSUNODA, K. YAMASHITA, M. OKUMURA and S. MIZUNO (1992): Isolation and characterization of alpha-1acid glycoprotein from horses, and its evaluation as an acute-phase reactive protein in horses. Am. J. Vet. Res. 53, 961-965.
34. TILLMANN, T., K. KAMINO, C. DASENBROCK, H. ERNST, M. KOHLER, G. MORAWIETZ, E. CAMPO, A. CARDESA, L. TOMATIS and U. MOHR (1997): Subcutaneous soft tissue tumours at the site of implanted microchips in mice. Exp. Toxicol. Pathol. 49, 197-200.

35. VASCELLARI, M., E. MELCHIOTTI and F. MUTINELLI (2006): Fibrosarcoma with typical features of postinjection sarcoma at site of microchip implant in a dog: histologic and immunohistochemical study. Vet. Pathol. 43, 545-548.

36. VASCELLARI, M., F. MUTINELLI, R. COSSETTINI and E. ALTINIER (2004): Liposarcoma at the site of an implanted microchip in a dog. Vet. J. 168, 188-190.

37. WITHROW, S. J. and E. G. MACEWEN (2001): Small Animal Clinical Oncology. WB Saunders. Philadelphia. $3^{\text {rd }}$ edition, pp. 296-301.

38. WULF, M., P. WOHLSEIN, J. E. AURICH, M. NEES, W. BAUMGÄRTNER and C. AURICH (2013a): Readability and histological biocompatibility of microchip transponders in horses. Vet. J. 198, 103-108.

39. WULF, M., C. AURICH, M. VON LEWINSKI, E. MÖSTL and J. E. AURICH (2013b): Reduced-size microchips for identification of horses: response to implantation and readability during a six-month period. Vet. Rec. 173,451

\section{Microchipping of animals and possible adverse effects in veterinary medicine}

Tihana JOSIPOVIĆ, DVM, Brežice, Slovenia; Hrvoje CAPAK, DVM, PhD, Assistant Professor, Lucija CIGLAR, student, Krešimir MARTINKOVIĆ, DVM, MSc, Faculty of Veterinary Medicine University of Zagreb, Croatia

Microchipping of animals has proven to be the most useful animal marking technique. Due to its high efficiency and easy application, it quickly reached a global scale. Microchipping in the Republic of Croatia may only be performed by authorized veterinarians who are obliged to abide by the legislation regulating implantation. The microchip is a passive device and its presence causes no harm to the animal. Since its common use as an animal marking technique, only a few studies have reported side effects.
Most of the side effects are excessive body reactions, tumours, incorrect implantation and migration. Although side effects are possible, today's technological advancements in the area of biocompatibility and duration of microchips have reduced the risk of side effects to a minimum. Additionally, the veterinarian's responsibility for proper implantation also plays a role in reducing this risk.

Key words: animals; marking; identification; microchip; microchipping 